Д. Ю. Федотов

Байкальский государственный университет, г. Иркутск, Российккая Федерация

Л. Ю. Климова

Забайкальский государственный университет,

2. Чита, Российская Федерация

\title{
ВНЕДРЕНИЕ ФИНАНСОВОГО МЕНЕДЖМЕНТА \\ НА ПРЕДПРИЯТИЯХ МАЛОГО БИЗНЕСА \\ С УЧЕТОМ ПРИМЕНЯЕМОГО НАЛОГОВОГО РЕЖИМА
}

АНнотАция. В сложившихся финансовых условиях, в которых оказались российские предприниматели, перед малым бизнесом страны стоит задача формирования финансовой системы управления предприятием в условиях современного налогообложения. В этой связи большое значение приобретает изучение особенностей организации финансового менеджмента на предприятиях малого бизнеса, способных в специфических условиях экономики страны и региона определить направления деятельности своего финансового развития. В статье рассмотрены основные проблемы и отличия функционирования финансового менеджмента как системы управления предприятием малого бизнеса в аспекте сравнения крупного предпринимательства, особенностей налогообложения и ведения бухгалтерской / финансовой отчетности. Дается характеристика основных областей деятельности и функций финансового менеджмента на предприятии и и приводятся критерии их оценки. Определяются специфические особенности финансового менеджмента в зависимости от системы налогообложения малого предприятия. Сравнение этих и других позиций свидетельствует о необходимости внедрения актуальной прогрессивной системы финансового менеджмента в секторе малого бизнеса для более эффективной работы с финансовыми ресурсами, повышения ликвидности, платежеспособности и финансовой устойчивости в современных реалиях нестабильного экономического состояния страны.

кЛючЕВЫЕ словА. Малый бизнес; финансовый менеджмент; налоговый режим; учет и контроль; планирование; денежный поток.

ФИНАНСИРОВАНИЕ. Государственное задание № 26.1348.2014/К на выполнение научно-исследовательских работ в сфере научной деятельности в рамках проектной части, проект № 1348 «Влияние теневого сектора экономики на качество жизни населения в России и Украине: сравнительный анализ» (номер госрегистрации в ФГАНУ ЦИТИС 114091140015).

ИНФОРМАЦИЯ О СТАТЬЕ. Дата поступления 29 марта 2016 г.; дата принятия к печати 7 мая 2016 г.; дата онлайн-размещения 29 июля 2016 г.

D. Yu. Fedotov Baikal State University, Irkutsk, Russian Federation

L. Yu. Klimova

Zabailkalye State University, Chita, Russian Federation

\section{INTRODUCTION OF FINANCIAL MANAGEMENT IN SMALL BUSINESSES IN VIEW OF EXISTING TAX REGIME}

ABSTRACT. Given the financial situation that involves Russian businesses, the country's small business faces the task of developing a financial system of corporate management in terms of present-day taxation. In that context, of great significance is studying the features of financial management functioning in small businesses that

(с) Д. Ю. Федотов, Л. Ю. Климова, 2016

\section{Baikal Research Journal}


are able to identify the directions of their financial development activity in specific economic environment of the country and the region. The article considers fundamental problems and functional differences of financial management as a system of managing a small enterprise in the context of comparing large-sized business, taxation features and accounting / financial reporting. It gives characteristic of major fields of financial management activities and functions in the enterprise and brings forth their assessment criteria. It identifies specific features of financial management depending on the taxation system of a small enterprise. Comparison of these and other positions attests the necessity of introducing an essential progressive system of financial management in the small business sector aimed at working more effectively with financial resources, increasing liquidity, paying capacity and financial stability in present-day realities of the country's unstable economic status.

KEYWORDS. Small business; financial management; tax regime; accounting and control; planning; flow of money.

FINANCING. This article was written with the financial support from State task № 26.1348.2014/K for research, Project № 1348 «Influence of shadow economy on the quality of life of the population in Russia and Ukraine: comparative analysis» (number of state registration at the Federal Center of Information Technology and Systems 114091140015). ARTICLE INFO. Received March 29, 2016; accepted May 7, 2016; available online July 29, 2016.

Существенные различия между крупным и малым бизнесом обуславливают необходимость пересмотра основных принципов финансового менеджмента, успешно применяемых на крупных предприятиях. Наиболее важные различия состоят в доступе к ресурсам, постановке целей, в степени риска и уровне ликвидности.

Финансовый менеджмент в практике работы рассматривается как система управления финансами предприятия, имеющего достаточно большие финансовые ресурсы, денежные потоки и открытый доступ на фондовый рынок. Кроме того, в части анализа финансового состоянии предприятия имеются достаточные информационные потоки как внешнего, так и внутреннего характера. Отечественные и зарубежные специалисты дают свое видение понятия «финансовый менеджмент» (табл. 1). В чем-то они схожи, а в чем-то разнятся, но в большинстве своем ведут речь о финансах крупного предприятия.

Структура имущественного состояния предприятий крупного бизнеса имеет широкий спектр источников формирования и финансирования. Все это дает широкие возможности работы и управления финансовой деятельностью и финансовым состоянием предприятий сферы крупного предпринимательства.

Это же и возводит определенные трудности при формировании системы финансового менеджмента на предприятиях малого сектора. Как правило, отечественные ученные рассматривают ограниченные возможности функционирования финансового менеджмента малого бизнеса с позиции недостаточности информативности финансовых показателей, в частности это связанно с упрощенной системой налогообложения малых предприятий и, как следствие, с упрощенной бухгалтерской отчетностью, а также с незначительной структурой активов предприятия — что не дает полной возможности анализа финансового состояния малого предприятия и организации финансовой деятельности [7, с. 11].

В то же время мировая практика показывает, что такая позиция в сфере политики организации финансовой работы на предприятиях малого бизнеса в условиях высоких финансовых рисков может привести к существенным финансовым потерям и банкротству предприятия. Это определяет актуальность разработки системы финансового менеджмента, его специфических особенностей именно для предприятий сферы малого бизнеса.

\section{Baikal Research Journal}

электронный научный журнал Байкальского государственного университета 
Определение понятия "финансовый менеджмент" в трактовке различных ученых

\begin{tabular}{|c|c|c|}
\hline Автор & Определение & Специфика подхода \\
\hline $\begin{array}{l}\text { В. В. Кова- } \\
\text { лев }\end{array}$ & $\begin{array}{l}\text { Финансовый менеджмент представляет собой систему } \\
\text { отношений, возникающих на предприятии и по поводу } \\
\text { привлечения и использования финансовых ресурсов. } \\
\text { Учитывая, что любые действия по реализации финансовых } \\
\text { отношений, в частности, в приложении к коммерческой ор- } \\
\text { ганизации, немедленно сказываются на ее имущественном } \\
\text { и финансовом положении, финансовый менеджмент можно } \\
\text { также трактовать как систему действий по оптимизации ее } \\
\text { баланса [1, с. } 87]\end{array}$ & $\begin{array}{l}\text { Слияние бухгалтер- } \\
\text { ского учета, финан- } \\
\text { сового анализа и } \\
\text { финансового менедж- } \\
\text { мента }\end{array}$ \\
\hline $\begin{array}{l}\text { И. Т. Бала- } \\
\text { банов }\end{array}$ & $\begin{array}{l}\text { Финансовый менеджмент - процесс выработки цели } \\
\text { управления финансами и осуществление воздействия на } \\
\text { них с помощью методов и рычагов финансового механиз- } \\
\text { ма. Он направлен на управление движением финансовых } \\
\text { ресурсов и финансовых отношений, возникающих между } \\
\text { хозяйствующими субъектами в процессе движения фи- } \\
\text { нансовых ресурсов. Как искусно руководить этим дви- } \\
\text { жением и отношениями - это содержание финансового } \\
\text { менеджмента [2, с. 15] }\end{array}$ & $\begin{array}{l}\text { Общая система } \\
\text { финансового ме- } \\
\text { неджмента (банков- } \\
\text { ский менеджмент, } \\
\text { маркетинговый } \\
\text { менеджмент, инно- } \\
\text { вационный и инве- } \\
\text { стиционный менед- } \\
\text { жмент) }\end{array}$ \\
\hline $\begin{array}{l}\text { Е. С. Стоя- } \\
\text { нова }\end{array}$ & $\begin{array}{l}\text { Финансовый менеджмент - наука управления финансами } \\
\text { предприятия, направленная на достижение его стратеги- } \\
\text { ческих и тактических целей. Эти цели индивидуальны для } \\
\text { каждого хозяйствующего субъекта }[3, \text { с. } 18]\end{array}$ & $\begin{array}{l}\text { Ориентированность } \\
\text { на стратегический и } \\
\text { оперативно-такти- } \\
\text { ческий финансовый } \\
\text { менеджмент } \\
\end{array}$ \\
\hline Е. И. Шохин & $\begin{array}{l}\text { Финансовый менеджмент представляет собой систему } \\
\text { знаний по эффективному управлению денежными фондами } \\
\text { и финансовыми ресурсами предприятий для достижения } \\
\text { стратегических целей и решения тактических задач } \\
{[4, \text { с. 21] }}\end{array}$ & $\begin{array}{l}\text { Методы финансово- } \\
\text { го планирования, } \\
\text { прогнозирования } \\
\text { и формирования } \\
\text { инвестиционной } \\
\text { стратегии }\end{array}$ \\
\hline И. А. Бланк & $\begin{array}{l}\text { Финансовый менеджмент представляет собой систему } \\
\text { принципов и методов разработки и реализации управленче- } \\
\text { ских решений, связанных с формированием, распределени- } \\
\text { ем и использованием финансовых ресурсов предприятия и } \\
\text { организацией оборота его денежных средств [5, с. } 33]\end{array}$ & $\begin{array}{l}\text { Система работы и } \\
\text { функционирования } \\
\text { наемного управляю- } \\
\text { щего }\end{array}$ \\
\hline $\begin{array}{l}\text { Ю. Бри- } \\
\text { гхем, Л. Га- } \\
\text { пенски }\end{array}$ & $\begin{array}{l}\text { Финансовый менеджмент - наука, посвященная методоло- } \\
\text { гии и технике управления финансами крупной корпорации } \\
{[6, \text { с. 54] }}\end{array}$ & $\begin{array}{l}\text { Долгосрочная фи- } \\
\text { нансовая политика } \\
\text { крупной компании } \\
\end{array}$ \\
\hline
\end{tabular}

Независимо от выбора схемы построения управления, организация финансов в любой отрасли и на предприятиях разного организационно-правового статуса строится на единых базовых принципах:

- экономическая самостоятельность;

- самофинансирование;

- материальная заинтересованность;

- финансовая ответственность;

- контроль, включая внутренний аудит;

- резервирование под финансовые риски.

При общности принципов управления финансами в различных формах организации предпринимательства, а также в разных отраслях и сферах экономики возникают специфические особенности финансовых отношений: различны структуры источников финансирования, включая доступ к финансовым рынкам и банковским

\section{Baikal Research Journal}

электронный научный журнал Байкальского государственного университета 
Таблица 2

Область деятельности, функиии и критерии оценки финансового менеджлента

\begin{tabular}{|c|c|c|}
\hline $\begin{array}{c}\text { Область дея- } \\
\text { тельности }\end{array}$ & Функции финансового менеджмента & Критерии оценки \\
\hline \multirow[t]{3}{*}{$\begin{array}{l}\text { Управление } \\
\text { денежными } \\
\text { потоками }\end{array}$} & $\begin{array}{l}\text { Регулирование и контроль денежных пото- } \\
\text { ков по производственной, инвестиционной, } \\
\text { финансовой деятельности УӘnPK }\end{array}$ & \multirow{3}{*}{$\begin{array}{l}\text { Прямой и косвенный методы } \\
\text { оценки денежных потоков, а также } \\
\text { ликвидный метод. Расчет чистого } \\
\text { денежного потока по трем видам } \\
\text { деятельности предприятия, а также } \\
\text { результативного денежного потока }\end{array}$} \\
\hline & $\begin{array}{l}\text { Получение, хранение, выплата наличных } \\
\text { денег, ценных бумаг УдnПX }\end{array}$ & \\
\hline & Взысканье денежных средств УӘ $n B$ & \\
\hline \multirow[t]{6}{*}{$\begin{array}{l}\text { Планирова- } \\
\text { ние }\end{array}$} & $\begin{array}{l}\text { Участие в долгосрочном и краткосрочном } \\
\text { финансовом планирование Пффn }\end{array}$ & \multirow{6}{*}{$\begin{array}{l}\text { Процедура составления бюджета. } \\
\text { Форма бюджета (план прибыли, } \\
\text { бюджет денежных средств, баланс). } \\
\text { Схема формирования финансовых } \\
\text { результатов, методы разнесения за- } \\
\text { трат. Состав используемых нормати- } \\
\text { вов. Оценка эффективности }\end{array}$} \\
\hline & Бюджетирование Пб & \\
\hline & Оценка эффективности затрат Пэз & \\
\hline & Анализ финансовых результатов Пфз & \\
\hline & Планирование объема продаж Побn & \\
\hline & Проведение ценовой политики Пцп & \\
\hline \multirow{3}{*}{$\begin{array}{l}\text { Управление } \\
\text { структурой } \\
\text { капитала }\end{array}$} & $\begin{array}{l}\text { Определение соотношения собственного и } \\
\text { привлеченного капитала УскСП }\end{array}$ & \multirow{3}{*}{$\begin{array}{l}\text { Поэлементная оценка стоимости } \\
\text { собственного и заемного капитала. } \\
\text { Средневзвешенная и предельная } \\
\text { цена капитала. Финансовый леве- } \\
\text { ридж }\end{array}$} \\
\hline & $\begin{array}{l}\text { Поиск путей долгосрочного финансирования } \\
\text { УскДФ }\end{array}$ & \\
\hline & Определение источников заемных средств УскЗС & \\
\hline \multirow{3}{*}{$\begin{array}{l}\text { Учет и кон- } \\
\text { троль }\end{array}$} & Определение учетной политики УКуп & \multirow{3}{*}{$\begin{array}{l}\text { Финансовый и операционный ана- } \\
\text { лиз. Управленческий учет. } \\
\text { SWOT-анализ деятельности предпри- } \\
\text { ятия }\end{array}$} \\
\hline & Подготовка различных видов отчетности УКво & \\
\hline & $\begin{array}{l}\text { Сравнение фактических результатов с плано- } \\
\text { выми и нормативными УКпн }\end{array}$ & \\
\hline \multirow{3}{*}{$\begin{array}{l}\text { Реализация } \\
\text { налоговой } \\
\text { политики }\end{array}$} & Разработка налоговой политики НПр & \multirow{3}{*}{$\begin{array}{l}\text { Анализ и оценка входящих и исходя- } \\
\text { щих налоговых потоков. Предпола- } \\
\text { гает использование предоставляемых } \\
\text { законом льгот и приемов сокращения } \\
\text { налоговых обязательств перед бюд- } \\
\text { жетом }\end{array}$} \\
\hline & Планирование налогов и сборов $H \Pi n$ & \\
\hline & Подготовка налоговой отчетности НПот & \\
\hline \multirow{4}{*}{$\begin{array}{l}\text { Минимиза- } \\
\text { ция рисков }\end{array}$} & Структурирование рисков Рcp & \multirow{4}{*}{$\begin{array}{l}\text { Результативность, оптимальное соот- } \\
\text { ношение риска и доходности. Общая } \\
\text { экономичность }\end{array}$} \\
\hline & Формирование фондов и резервов $Р \not p$ & \\
\hline & Анализ конъюнктуры фондового рынка Ркр & \\
\hline & Формирование инвестиционного портфеля Pun & \\
\hline \multirow{2}{*}{$\begin{array}{l}\text { Разработка } \\
\text { информа- } \\
\text { ционных } \\
\text { систем } \\
\text { управления } \\
\text { ИСУ }\end{array}$} & $\begin{array}{l}\text { Изучение современных информационных } \\
\text { систем управления СУи }\end{array}$ & \multirow{2}{*}{$\begin{array}{l}\text { Достоверность, своевременность } \\
\text { внешних и внутренних потоков } \\
\text { информации. Критерии эффективно- } \\
\text { сти использования информационной } \\
\text { системы управления в структуре ор- } \\
\text { ганизации управления предприятием }\end{array}$} \\
\hline & Оценка программного обеспечения СУпо & \\
\hline \multirow{3}{*}{$\begin{array}{l}\text { Инвести- } \\
\text { ционные } \\
\text { решения }\end{array}$} & Определение потребности в инвестициях Ипи & \multirow{3}{*}{$\begin{array}{l}\text { Методы, основанные на дисконтиро- } \\
\text { ванных оценках («динамические» } \\
\text { методы): NPV/PI/ IRR/ DPP и мето- } \\
\text { ды, основанные на учетных оценках } \\
\text { («статистические» методы): PP/ ARR }\end{array}$} \\
\hline & $\begin{array}{l}\text { Определение размера ожидаемых денежных } \\
\text { поступлений ИӘn }\end{array}$ & \\
\hline & Разработка инвестиционной политики Ири & \\
\hline \multirow{3}{*}{$\begin{array}{l}\text { Кратко- } \\
\text { срочные } \\
\text { финансовые } \\
\text { решения }\end{array}$} & $\begin{array}{l}\text { Определение притоков и оттоков денежных } \\
\text { средств в течении или менее года } К \Phi P \partial n\end{array}$ & \multirow{3}{*}{$\begin{array}{l}\text { Нормирование оборотных средств } \\
\text { предприятия. Коэффициенты обора- } \\
\text { чиваемости. Рентабельность исполь- } \\
\text { зования }\end{array}$} \\
\hline & $\begin{array}{l}\text { Установление потребности в оборотных сред- } \\
\text { ствах КФРос }\end{array}$ & \\
\hline & $\begin{array}{l}\text { Выявление источников формирования оборот- } \\
\text { ных средств и эффективное распоряжение ими } \\
\text { КФРиф }\end{array}$ & \\
\hline
\end{tabular}

\section{Baikal Research Journal}

электронный научный журнал Байкальского государственного университета 
кредитам, разнятся набор активов, степень их ликвидности, скорость оборота капитала, объемы и интенсивность денежных потоков, структура издержек, доходность операций, уровень рисков.

Для того чтобы повысить эффективность финансовой деятельности на субъектах сектора малого бизнеса, необходимо рассмотреть область деятельности и функции финансового менеджмента (табл. 2).

Рассмотрим области деятельности финансового менеджмента более подробно.

Управление денежными потоками является основой любой коммерческой деятельности. Рациональное управление денежными потоками позволит предприятию получать дополнительную прибыль, уменьшить издержки и снизить операционные риски. Специфика оценки и анализа денежных потоков в малом бизнесе сводится к недостаточности притоков и оттоков денежных средств по трем видам деятельности. Как правило, в малом бизнесе есть потоки по операционной деятельности, а у некоторых по финансовой. Если есть долгосрочные и краткосрочные обязательства, то практически отсутствует инвестиционная деятельность [8, с. 18].

Как для крупного бизнеса, так и для малого составление планов помогает принять правильное управленческое решение в конкретных условиях развития, а так как у малого бизнеса не такие широкие возможности для маневров, то очень многое зависит от качества планирования. Планирование в малом бизнесе должно опираться на данные бухгалтерских отчетов, так как только из этих документов можно получить достоверные данные об эффективности коммерческой деятельности. В этом случае опять возникает проблема нехватки информативных показателей. Для малого предпринимательства наиболее актуальны: план продаж, финансовый план и производственный план.

Управление структурой капитала рассматривают как нечто производное, как показатель, играющий второстепенную роль, при этом на первое место, как правило, выносится непосредственно сам процесс деятельности предприятия. Однако доход и прибыль приносит предприятию именно процесс использования капитала, а не деятельность предприятия как таковая. Все это определяет существенную значимость процесса управления финансами малого предприятия на различных этапах его существования.

В настоящее время постановка учета на предприятиях малого бизнеса рассматривается с позиции совершенствования бухгалтерского учета, ориентированного на требования налогового законодательства, что не способствует повышению информационной ценности учетных данных для эффективного управления и контроля. Между тем потребность в разработке схемы построения учета, обеспечивающая рациональный учетный процесс и формирование информации для целей управления и контроля, на малых предприятиях становится острой и настоятельной $[9$, с. 13].

Реализация налоговой политики малого бизнеса осуществляется в рамках четырех из пяти специальных налоговых режимов: упрощенная система налогообложения, единый налог на вмененный доход для отдельных видов деятельности, патентная система, единый сельскохозяйственный налог. Наиболее популярный и распространенный режим в России - упрощенная система налогообложения, рассчитанный на малое и среднее предпринимательство и ориентированный на снижение налогового бремени посредством облегчения ведения отчетности. Налоговые вопросы и регулирование налоговых рисков в деятельности малого бизнеса подробно рассматриваются в трудах отечественных ученых [10].

Структурирование рисков, формирование фондов и резервов - такая же важная составляющая предпринимательской деятельности, как и реклама, аренда и др.

\section{Baikal Research Journal}


Как бы точно ни рассчитывал предприниматель предстоящие изменения внешней среды, невозможно точно предугадать то, что случится в будущем. Во всем мире постоянно происходят изменения. Меняется жизнь общества, запросы потребителей, партнеров, клиентов. Исходя из этого, необходимо совершенствовать и модернизировать свое предприятие, но развитие предполагает увеличение не только количества рисков, но и их разнообразия, поэтому одной из первостепенных задач предпринимателя является минимизация рисков посредством оперативной информации, планирования и страхования [11-13].

Если для крупного предпринимательства необходимость разработки информационных систем управления - вопрос, решенный и однозначный, то активное применение информационных технологий совсем небольшими предприятиями - тема до сих пор не всегда очевидная руководителям таких фирм. Малые предприятия не менее зависимы от информационных технологий, чем крупные организации. В небольших предприятиях все участки учета курирует один бухгалтер, причем нередко он обслуживает несколько организаций. Поток документов здесь не столь велик, как в крупных организациях, зато бухгалтеру приходится работать со всем их спектром, а не с какой-то частью и оперативно «подстраивать» учет под вновь возникающие задачи предприятия, находить способы отражения новых хозяйственных операций и бизнес-процессов. Все это требует разработки эффективной информационной системы именно малого предприятия.

Инвестиционные процессы малого бизнеса имеют ряд особенностей, которые обеспечивают им преимущества перед инвестиционным процессом крупных предприятий. Некоторые из этих преимуществ определяются и организационными особенностями малых предприятий. Это в первую очередь то, что малые предприятия по сравнению с крупными требуют меньшего объема капитальных вложений как в абсолютной сумме, так и в пересчете на одного работающего. Малые предприятия также обеспечивают более быстрый срок окупаемости инвестиций, нехватка капитала ориентирует малые предприятия на быструю прибыль и т. д. Все это должно способствовать принятию инвестиционных решений в секторе малого предпринимательства.

Краткосрочные финансовые решения - это, прежде всего, управление оборотным капиталом предприятия: денежными средствами и ликвидными ценными бумагами, производственными запасами, дебиторской и кредиторской задолженностью. Определение необходимого уровня оборотных средств и краткосрочной кредиторской задолженности, от которых зависит состояние текущих активов предприятия, включает в себя решения о ликвидности ее активов и очередности выплат ее долгов. На эти решения в свою очередь влияет выбор между прибыльностью и риском.

Все эти особенности говорят о необходимости внедрения более современной и прогрессивной системы финансового менеджмента на предприятиях малого бизнеca, учитывающей специфические особенности финансовой деятельности, особенностей налогообложения и введения бухгалтерской / финансовой отчетности.

Рассмотрим круг возможностей финансового менеджмента в малом бизнесе, исходя из области деятельности и функций в сравнении с крупным предпринимательством с учетом применяемого налогового режима. Различия в значительной степени проявляются в наличии у субъектов малого предпринимательства возможности выбрать либо общую систему налогообложения, либо одну из четырех специальных режимов: широкие возможности; незначительные ограничения; ссуженный круг возможностей; невозможность применения. Из представленных данных (табл. 3) видно, что не все области и функции финансового менеджмента доступны и актуальны для малого предпринимательства. Это касается в частности

\section{Baikal Research Journal}

электронный научный журнал Байкальского государственного университета 
Таблица 3

Специфика деятельности и функций финансового менеджлента в зависимости от системы налогообложения малого предпринимательства

\begin{tabular}{|c|c|c|c|c|c|c|c|c|}
\hline \multirow[t]{2}{*}{$\begin{array}{c}\text { Область } \\
\text { деятельности }\end{array}$} & \multirow{2}{*}{$\begin{array}{c}\text { Функции } \\
\text { финансового } \\
\text { менеджмента }\end{array}$} & \multirow{2}{*}{$\begin{array}{c}\begin{array}{c}\text { Большие } \\
\text { предприятия }\end{array} \\
\text { ОСН }\end{array}$} & \multicolumn{2}{|c|}{$\begin{array}{c}\text { Малые } \\
\text { предприятия }\end{array}$} & \multicolumn{2}{|c|}{$\begin{array}{l}\text { Индивидуальные } \\
\text { предприниматели }\end{array}$} & \multicolumn{2}{|c|}{$\begin{array}{c}\text { Микро- } \\
\text { предприятия }\end{array}$} \\
\hline & & & CHP & $\mathrm{OCH}$ & $\mathrm{CHP}$ & $\mathrm{OCH}$ & $\mathrm{CHP}$ & $\mathrm{OCH}$ \\
\hline \begin{tabular}{|l} 
Управление денеж- \\
ными потоками
\end{tabular} & $\begin{array}{c}У \partial n P K \\
У \partial n \Pi X \\
У \partial n B\end{array}$ & $\begin{array}{l}+++ \\
+++ \\
+++\end{array}$ & $\begin{array}{l}+++ \\
+++ \\
+++\end{array}$ & $\begin{array}{l}+++ \\
++- \\
+++\end{array}$ & $\begin{array}{l}++- \\
++- \\
+--\end{array}$ & $\begin{array}{l}++- \\
++- \\
+--\end{array}$ & $\begin{array}{l}+-- \\
+-- \\
+--\end{array}$ & $\begin{array}{l}+-- \\
+-- \\
+--\end{array}$ \\
\hline Планиров & $\begin{array}{c}\Pi ф n \\
\Pi б \\
\Pi ә з \\
\Pi ф з \\
\Pi о б n \\
\Pi u n\end{array}$ & $\begin{array}{l}+++ \\
+++ \\
+++ \\
+++ \\
+++ \\
+++\end{array}$ & $\begin{array}{l}+++ \\
+++ \\
+++ \\
+++ \\
+++ \\
+++\end{array}$ & $\begin{array}{l}+++ \\
+++ \\
+++ \\
+++ \\
+++ \\
+++\end{array}$ & $\begin{array}{l}++- \\
++- \\
+++ \\
+++ \\
+++ \\
+++\end{array}$ & $\begin{array}{l}++- \\
++- \\
+++ \\
+++ \\
+++ \\
+++\end{array}$ & $\begin{array}{c}+-- \\
+-- \\
+++ \\
+++ \\
+++ \\
+++\end{array}$ & $\begin{array}{l}+-- \\
+-- \\
+++ \\
+++ \\
+++ \\
+++\end{array}$ \\
\hline $\begin{array}{l}\text { Управление струк- } \\
\text { турой капитала }\end{array}$ & $\begin{array}{l}У с к С П \\
У с к Д \Phi \\
У с к З С\end{array}$ & $\begin{array}{l}+++ \\
+++ \\
+++\end{array}$ & $\begin{array}{l}+++ \\
+++ \\
+++\end{array}$ & $\begin{array}{l}+++ \\
+++ \\
+++\end{array}$ & $\begin{array}{l}+++ \\
++- \\
+++\end{array}$ & $\begin{array}{l}+++ \\
++- \\
+++\end{array}$ & $\begin{array}{l}+++ \\
+-- \\
+++\end{array}$ & $\begin{array}{l}+++ \\
+-- \\
+++\end{array}$ \\
\hline Учет и контроль & $\begin{array}{l}\text { УKyn } \\
\text { УКво } \\
\text { УКпн }\end{array}$ & $\begin{array}{l}+++ \\
+++ \\
+++\end{array}$ & $\begin{array}{l}+++ \\
+++ \\
+++\end{array}$ & $\begin{array}{l}+++ \\
+++ \\
+++\end{array}$ & $\begin{array}{l}+++ \\
+++ \\
+++\end{array}$ & $\begin{array}{l}+++ \\
+++ \\
+++\end{array}$ & $\begin{array}{l}+++ \\
+++ \\
+++\end{array}$ & $\begin{array}{l}+++ \\
+++ \\
+++\end{array}$ \\
\hline \begin{tabular}{|l|} 
Реализация налого- \\
вой политики
\end{tabular} &  & $\begin{array}{l}+++ \\
+++ \\
+++\end{array}$ & $\begin{array}{l}+++ \\
+++ \\
+++\end{array}$ & $\begin{array}{l}+++ \\
+++ \\
+++\end{array}$ & $\begin{array}{l}+++ \\
+++ \\
+--\end{array}$ & $\begin{array}{l}+++ \\
+++ \\
+++\end{array}$ & $\begin{array}{l}+++ \\
+-- \\
---\end{array}$ & $\begin{array}{l}+++ \\
+-- \\
---\end{array}$ \\
\hline $\begin{array}{l}\text { Минимизация } \\
\text { рисков }\end{array}$ & $\begin{array}{l}P c p \\
P \phi p \\
P \kappa p \\
P u n\end{array}$ & $\begin{array}{l}+++ \\
+++ \\
+++ \\
+++\end{array}$ & $\begin{array}{l}+++ \\
++- \\
+-- \\
+--\end{array}$ & $\begin{array}{l}+++ \\
++- \\
+-- \\
+--\end{array}$ & $\begin{array}{l}+++ \\
+-- \\
+-- \\
---\end{array}$ & $\begin{array}{l}+++ \\
+-- \\
+-- \\
---\end{array}$ & $\begin{array}{l}+++ \\
--- \\
--- \\
---\end{array}$ & $\begin{array}{l}+++ \\
--- \\
--- \\
---\end{array}$ \\
\hline $\begin{array}{l}\text { Разработка инфор- } \\
\text { мационных систем } \\
\text { управления ИСУ } \\
\end{array}$ & $\begin{array}{l}\text { CУи } \\
\text { СУno }\end{array}$ & $\begin{array}{l}+++ \\
+++\end{array}$ & $\begin{array}{l}+++ \\
+++\end{array}$ & $\begin{array}{l}+++ \\
+++\end{array}$ & $\begin{array}{l}+-- \\
+--\end{array}$ & $\begin{array}{l}+-- \\
+--\end{array}$ & $\begin{array}{l}--- \\
---\end{array}$ & $\begin{array}{l}--- \\
---\end{array}$ \\
\hline $\begin{array}{l}\text { Инвестиционные } \\
\text { решения }\end{array}$ & $\begin{array}{l}\text { Иnu } \\
\text { Иən } \\
\text { Ирu }\end{array}$ & $\begin{array}{l}+++ \\
+++ \\
+++\end{array}$ & $\begin{array}{l}+++ \\
++- \\
++-\end{array}$ & $\begin{array}{l}+++ \\
++- \\
++-\end{array}$ & $\begin{array}{l}+++ \\
+-- \\
+--\end{array}$ & $\begin{array}{l}+++ \\
+-- \\
+--\end{array}$ & $\begin{array}{l}+++ \\
+-- \\
+--\end{array}$ & $\begin{array}{l}+++ \\
+-- \\
+--\end{array}$ \\
\hline $\begin{array}{l}\text { Краткосрочные фи- } \\
\text { нансовые решения }\end{array}$ & $\begin{array}{l}\kappa \Phi P \partial n \\
K \Phi P o c \\
\kappa \Phi P u ф\end{array}$ & $\begin{array}{l}+++ \\
+++ \\
+++\end{array}$ & $\begin{array}{l}+++ \\
+++ \\
+++\end{array}$ & $\begin{array}{l}+++ \\
+++ \\
+++\end{array}$ & $\begin{array}{l}+++ \\
+++ \\
+++\end{array}$ & $\begin{array}{l}+++ \\
+++ \\
+++\end{array}$ & $\begin{array}{l}+++ \\
+++ \\
+++\end{array}$ & $\begin{array}{l}+++ \\
+++ \\
+++\end{array}$ \\
\hline
\end{tabular}

Прилечание. СНР - специальный налоговый режим; ОСН - общая система налогообложения; + + + - широкие возможности; + + - - незначительные ограничения; + - - - ссуженный круг возможностей; - - - невозможность применения.

управления денежными потоками, упрощенной системой планирования и разработки инвестиционной политики. В процессе управления малым предприятием возникает также сложность в части анализа отдельных финансовых коэффициентов и общего финансового состояния предприятия. При этом мы можем с полной уверенностью говорить о том, что на таких предприятиях, возможно, сформировать специфическую систему финансового менеджмента, включающую основные сегменты деятельности предприятия и внедрить характерные приемы финансовой деятельности присущие крупному бизнесу. В частности, это касается планирования, управления структурой капитала и разработки политики финансирования деятельности предприятия.

Таким образом, можно сделать вывод, что на предприятиях малого предпринимательства может и должна функционировать система финансового менеджмента, разработанная либо самим предпринимателем как руководителем этого пред-

\section{Baikal Research Journal}

электронный научный журнал Байкальского государственного университета 
приятия, либо путем привлечения финансового консультанта, который определит основные области, сферы деятельности и функции финансового менеджмента непосредственно этого предприятия. В дальнейшем это будет способствовать более эффективной работе малого предприятия, снизит возможности возникновения финансовых рисков, определит основные параметры в части политики управления денежными потоками, активами и капиталом.

\section{Список использованной литературы}

1. Ковалев В. В. Финансовый менеджмент: теория и практика / В. В. Ковалев. - 3-е изд., перераб. и доп. - М. : Проспект, 2013. - 1104 с.

2. Балабанов И. Т. Основы финансового менеджмента : учеб. пособие / И. Т. Балабанов. 2-е изд., доп. и перераб. - М. : Финансы и статистика, 2009. - 512 с.

3. Финансовый менеджмент: теория и практика : учебник / под ред. Е. С. Стояновой. 6-е изд. - М. : Перспектива, 2010. - 656 с.

4. Финансовый менеджмент : учеб. пособие / под ред. Е. И. Шохина. - М. : ИД ФБКПресс, 2004. - $408 \mathrm{c}$.

5. Бланк И. А. Основы финансового менеджмента / И. А. Бланк. - Киев : Ника-Центр : Эльга, 2001. - Т. 1. - 592 с. - (Библиотека финансового менеджмента ; Вып. 3).

6. Бригхем Ю. Финансовый менеджмент: полный курс : в 2 т. / Ю. Бригхем, Л. Гапенски ; пер. с англ. под ред. В. В. Ковалева. - СПб. : Питер, 2001. - Т. 1. - 497 с. ; Т. 2. - 669 с.

7. Борисов А. Н. Организация финансового менеджмента на малых предприятиях / А. Н. Борисов // Финансовый менеджмент. - 2004. - № 6. - С. 5-12.

8. Понамаренко И. А. Некоторые аспекты управления денежными потоками в малом бизнесе / И. А. Понамаренко // Управленческий учет и финансы. - 2012. - № 2. - С. 100-106.

9. Корень А. В. Специальные налоговые режимы в реализации государственной политики по поддержке малого и среднего бизнеса / А. В. Корень, Ж. Ю. Крауберг // Международный журнал прикладных и фундаментальных исследований. $-2015 .-$ № 3. - C. 479-483.

10. Киреенко А. П. Налоговые риски в деятельности малого бизнеса [Электронный ресурс] / А. П. Киреенко // Известия Иркутской государственной экономической академии (Байкальский государственный университет экономики и права). -2010 . - № 5. - Режим доступа : http://brj-bguep.ru/reader/article.aspx?id=13887.

11. Муравьева Н. Н. Основание критериев эффективности управления финансовыми рисками в коммерческих организациях / Н. Н. Муравьева, Т. К. Блинова // Экономика и бизнес: теория и практика. - 2015. - № 1. - С. 65-70.

12. Смагин В. Н. Финансовый менеджмент. Краткий курс : учеб. пособие / В. Н. Смагин. - М. : КноРус, 2007. -144 с.

13. Ткачук М. И. Основы финансового менеджмента : учеб. пособие / М. И. Ткачук, Е. Ф. Киреева. - Минск : Интерпрессервис, Экоперспектива, 2002. - 416 с.

\section{References}

1. Kovalev V. V. Finansovyi menedzhment: teoriya i praktika [Financial management: Theory and Practice]. $3^{\text {rd }}$ ed. Moscow, Prospekt Publ., 2013. 1104 p.

2. Balabanov I. T. Osnovy finansovogo menedzhmenta [Basics of Financial Management]. $2^{\text {nd }}$ ed. Moscow, Finansy i statistika Publ., 2009. 512 p.

3. Stoyanova E. S. (ed.). Finansovyi menedzhment: teoriya i praktika [Financial Management: Theory and Practice]. $6^{\text {th }}$ ed. Moscow, Perspektiva Publ., 2010. 656 p.

4. Shokhin E. I. (ed.). Finansovyi menedzhment [Financial Management]. Moscow, FBKPress, 2004. $408 \mathrm{p}$.

5. Blank I. A. Osnovy finansovogo menedzhmenta [Basics of Financial Management]. Kiev, Nika-Tsentr Publ., El'ga Publ., 2001. Vol. 1. 592 p.

6. Brigham E. F., Gapenski L. C. Intermediate Financial Management. New York, The Dryden Press, 1996. 274 p. (Russ. ed.: Brigkhem Yu., Gapenski L. Finansovyi menedzhment. Polnyi kurs. Saint Petersburg, Piter Publ., 2001. Vol. 1. 497 p., Vol. 2. 669 p.).

7. Borisov A. N. Providing financial management in small businesses. Finansovyi menedzhment $=$ Financial Management, 2004, no. 6, pp. 5-12. (In Russian).

\section{Baikal Research Journal}


8. Ponamarenko I. A. Some aspects of managing cash flows in small business. Upravlencheskii uchet $i$ finansy = Management accounting and Finance, 2012, no. 2, pp. 100-106. (In Russian).

9. Koren' A. V., Krauberg Zh. Yu. Special tax regimes in implementing government policies to support small and medium-sized businesses. Mezhdunarodnyi zhurnal prikladnykh $i$ fundamental'nykh issledovanii = International Journal of Applied and Fundamental Research, 2015, no. 3, pp. 479-483. (In Russian).

10. Kireenko A. P. Tax risks in small businesses. Izvestiya Irkutskoi gosudarstvennoi ekonomicheskoi akademii (Baykalskii gosudarstvennyi universitet ekonomiki i prava) $=$ Bulletin of Irkutsk State Economics Academy (Baikal State University of Economics and Law), 2010, no. 5. Available at: http://brj-bguep.ru/reader/article.aspx?id=13887. (In Russian).

11. Muravyova N. N., Blinova T. K. Justification of criteria of efficiency of financial risk management in commercial organizations. Ekonomika $i$ biznes: teoriya i praktika $=$ Economics and Business: Theory and Practice, 2015, no. 1, pp. 65-70. (In Russian).

12. Smagin V. N. Finansovyi menedzhment. Kratkii kurs [Financial management. A Short Course]. Moscow, KnoRus Publ., 2007. 144 p.

13. Tkachuk M. I., Kireyeva E. F. Osnovy finansovogo menedzhmenta [Basics of Financial Management]. Minsk, Interpresservis Publ., Ekoperspektiva Publ., 2002. 416 p.

\section{Информация об авторах}

Федотов Длитрий Юрьевич - доктор экономических наук, профессор, декан факультета налогов и таможенного дела, Байкальский государственный университет, 664003, г. Иркутск, ул. Ленина, 11; e-mail: fdy@inbox.ru.

Климова Людмила Юрьевна - старший преподаватель, кафедра экономики и бухгалтерского учета, Забайкальский государственный университет, 672039, г. Чита. ул. Александро-Заводская, 30; e-mail: LUKlimova@mail.ru.

\section{Authors}

Dmitry Yu.Fedotov - Doctor habil. (Economics), Professor, Dean of Taxes and Customs Department, Baikal State University, 11 Lenin St., 664003, Irkutsk, Russian Federation; e-mail: fdy@inbox.ru.

Lyudmila Yu. Klimova - Senior Lecturer, Chair of Economics and Accounting, Zabaikalye State University, 30 Aleksandro-Zavodskaya St., 672039, Chita, Russian Federation; e-mail: LUKlimova@mail.ru.

\section{Библиографическое описание статьи}

Федотов Д. Ю. Внедрение финансового менеджмента на предприятиях малого бизнеса с учетом применяемого налогового режима / Д. Ю. Федотов, Л. Ю. Климова / Baikal Research Journal. — 2016. — T. 7, № 4. - DOI : 10.17150/2411-6262.2016.7(4).1.

\section{Reference to article}

Fedotov D. Yu., Klimova L. Yu. Introduction of financial management in small businesses in view of existing tax regime. Baikal Research Journal, 2016, vol. 7, no. 4. DOI : 10.17150/24116262.2016.7(4).1. (In Russian).

\section{Baikal Research Journal}

